Scientia Agricola

http://dx.doi.org/10.1590/0103-9016-2014-0099

\title{
Aminoethoxyvinylglycine: isolated and combined with other growth regulators on quality of 'Brookfield' apples after storage
}

\author{
Auri Brackmann*, Fabio Rodrigo Thewes, Rogerio de Oliveira Anese, Vanderlei Both, Wanderlei Linke Junior, Erani Eliseu Schultz
}

Federal University of Santa Maria/Postharvest Research Center - Dept. of Plant Science, Av. Roraima, 1000, Camobi - 97105-900 - Santa Maria, RS - Brazil.

${ }^{*}$ Corresponding author <auribrackmann@gmail.com>

Edited by: Luís Guilherme de Lima Ferreira Guido

Received March 13, 2014

Accepted September 04, 2014

\begin{abstract}
Growth regulators are used in the production of apples worldwide, especially to extend the harvest period and maintain postharvest quality. This study aimed to investigate the effects of applying aminoethoxyvinylglycine (AVG) in isolation as well as in combination with other growth regulators and postharvest techniques on the harvest quality and storage potential of 'Brookfield' apples (Malus domestica), a 'Gala' strain. Fruit receiving AVG only had the highest starch content and the highest titratable acidity at harvest. After 8 months of storage, the AVG + 1-MCP (1-methylcyclopropene) and AVG + ABS (ethylene absorption) conserved higher flesh firmness than to all the other treatments. Naphthaleneacetic acid (NAA) application induced ACC oxidase enzyme activity at harvest, but not after storage. AVG application, with or without the aid of another technique, did not decrease the red skin color of 'Brookfield' apples. Low mealiness and a high healthy fruit percentage was obtained when the fruits were submitted to pre-harvest AVG application combined with NAA, 1-MCP and ABS. Internal carbon dioxide had an inverse correlation with the quantity of healthy fruit and was directly correlated with mealiness.

Keywords: Malus domestica, postharvest quality, skin color, ethephon, naphthaleneacetic acid
\end{abstract}

\section{Introduction}

The application of growth regulators is necessary either to advance or to delay the fruit harvest in the field, due to the short period that fruit remains naturally at the correct maturation stage. Besides the short harvest period, another problem is that the harvest is carried out manually and requires a lot of time and manual labor. Thus, growth regulators are frequently used in the orchards.

The main growth regulator applied in the field is aminoethoxyvinylglycine (AVG) which is used to delay the harvest in order to avoid pre-harvest fruit drop (McFadyen et al., 2012; Yildiz et al., 2012). AVG blinds the active site of ACC (1- aminocyclopropane-1-carboxylate) synthase enzyme and inhibits ethylene production and maturation events initiated by this plant hormone (Yu and Yang, 1979; Huai et al., 2001). Despite the benefits promoted by AVG application, it decreases the red skin color of 'Gala' apples (Malus domestica) (Steffens et al., 2006). However, this reduction of red skin color has not yet been proven in 'Gala' mutants.

Another growth regulator used extensively is ethephon, mainly to advance the fruit harvest. Its application allows for an early harvest of the fruit, and also increases the red color of fruit skin (Li et al., 2001; Steffens et al., 2006; Ban et al., 2007). However, ethephon application may decrease organoleptic quality and decrease the storage potential of fruit after harvest, especially in terms of declines in flesh firmness (Steffens et al., 2006; Ban et al., 2007). As well as the application of ethephon, naphthaleneacetic acid (NAA) is also used during apple production. Its application reduces pre-harvest fruit drop in apples (Yuan and Carbaugh, 2007; Unrath et al., 2009), oranges (Zur and Goren, 1977) and decreases the fruit size (Black et al., 1995).
Other techniques are used to control ethylene and consequently fruit softening postharvest, such as 1-methylcyclopropene (1-MCP) application and ethylene absorption (ABS). 1-MCP application blinds the ethylene receptors, thereby inhibiting the ethylene action and consequently fruit ripening (Blankenship and Dole, 2003; Ma et al., 2006). Ethylene absorption is also carried out in apple storage occasionally. On 'Royal Gala' apples, the ethylene absorption had the same effect as $1-\mathrm{MCP}$ and low relative humidity on ripening control (Brackmann et al., 2011). Thus, this study aimed to investigate the effect of AVG both in isolation, and in combination with other growth regulators and postharvest techniques on the harvest quality and storage potential of 'Brookfield' apples.

\section{Materials and Methods}

\section{Plant material and treatments application}

Treatments were applied in 2012 in a commercial orchard in Vacaria $\left(28^{\circ} 30^{\prime} 44^{\prime \prime}\right.$ S; 5056'02" W; $971 \mathrm{~m}$ a.s.l.), in the state of Rio Grande do Sul - RS - Brazil. The orchard had a density of 3,575 plants ha ${ }^{-1}$, and the rootstocks used were M9. During the growing season, the following fertilization was carried out: $80 \mathrm{~kg} \mathrm{ha}^{-1}$ of nitrogen and $120 \mathrm{~kg} \mathrm{ha}^{-1}$ of potassium. The treatments were: (i) Control: water only application; (ii) AVG application (0.83 kg ha ${ }^{-1} 15 \%$ of active ingredient) 30 days before harvest $(\mathrm{BH})$; (iii) AVG + Ethephon (2.0 L ha ${ }^{-1}$ $24 \%$ of active ingredient) applied 10 days $\mathrm{BH}$; (iv) AVG + auxin $\left(40 \mathrm{~g} \mathrm{ha}^{-1}\right.$ of NAA applied 7 days BH); (v) AVG + Ethylene absorption with potassium permanganate (ABS) during postharvest; (vi) AVG + 1-MCP application $\left(0.625 \mu \mathrm{L} \mathrm{L}^{-1}\right)$ during postharvest, according to Corrêa et al. (2011). An output of 1,000 L ha-1 of water was applied 
in the treatments carried out in the field, according to Steffens et al. (2006). Each one of them consisted of four replications with four plants each.

\section{Harvest, fruit selection and storage conditions}

Each replication of 50 fruits was harvested and fruits that presented mechanical lesions or any other damage symptom were discarded. Then, the fruit selection process was once again carried out aiming to eliminate fruits that presented mechanical lesions, due to transportation. Immediately after this selection, samples of 25 fruits each were chosen and put into hermetically sealed chambers in order to install controlled atmosphere conditions $\left(1.2 \mathrm{kPa}\right.$ of $\mathrm{O}_{2}+2.0 \mathrm{kPa}$ of $\left.\mathrm{CO}_{2}\right)$. The storage temperature was $1.5{ }^{\circ} \mathrm{C}( \pm 0.1)$ and relative humidity $94 \%( \pm 1.0 \%)$, over a period of 8 months. During this storage period, the controlled atmosphere conditions were corrected daily with an automatic gas controller equipped with a gas analyzer.

\section{Fruit quality evaluation}

The following physical, chemical and biochemical parameters were evaluated: i) ACC oxidase enzyme activity: evaluated according to the methodology proposed by Bufler (1986); ii) ethylene production: determined by the storage of approximately $1.5 \mathrm{~kg}$ of fruits in a container with a volume of $5 \mathrm{~L}$, that was hermetically sealed for approximately $1 \mathrm{~h}$. Then two aliquots of $1 \mathrm{~mL}$ of each container were drawn and injected into a gas chromatograph equipped with a flame ionization detector (FID) and a Porapak N80/100 column. The temperatures of the column, the injector and the detector were 90, 140 and $200{ }^{\circ} \mathrm{C}$ respectively. Data were expressed in $\mu \mathrm{L} \mathrm{C}_{2} \mathrm{H}_{4} \mathrm{~kg}^{-1}$ $\mathrm{h}^{-1}$; iii) internal ethylene concentration (IEC) was determined according to the methodology proposed by Mannapperuma et al. (1991), whereby internal air from the fruit was withdrawn by a $565 \mathrm{~mm} \mathrm{Hg}$ suction pressure vacuum pump which removed air from the container filled with water in which the fruit was submerged. An inverted funnel, with a septum in its thinner end, covered the fruit, allowing the air removed from it to be accumulated. $1 \mathrm{~mL}$ samples of this air were injected in the same chromatograph used for ethylene production and the results were expressed in $\mu \mathrm{C} \mathrm{C}_{2} \mathrm{H}_{4} \mathrm{~L}^{-1}$ of the air from the fruit's internal space; iv) respiration rate: determined by using a chromatograph equipped with a capillary column, from the same 5 L-container used to establish the ethylene production. The data was expressed in $\left.\mathrm{mL} \mathrm{CO} \mathrm{kg}^{-1} \mathrm{~h}^{-1} ; \mathrm{v}\right)$ internal $\mathrm{CO}_{2}$ concentration $\left(\mathrm{ICO}_{2}\right)$ : determined by using the same gas chromatograph used to evaluate the respiration rate to obtain the $\mathrm{CO}_{2}$ concentration of two samples from the same air extracted to assess the IEC, the results were expressed in $\mathrm{mL} \mathrm{CO}$ $100 \mathrm{~mL}^{-1}$ of the air from the internal space of the fruit; vi) gas diffusion: evaluated according to the method proposed by Schotsmans et al. (2003) with adaptations; vii) flesh firmness: determined with the aid of a penetrometer equipped with a 11-mm tip, being expressed in
Newtons; viii) flesh breakdown; ix) decay incidence; $\mathrm{x}$ | mealiness: xi) healthy fruits: determined by counting the fruits that showed such disorders, data were presented in percentages; xii): red skin color index: assessed subjectively through the identification of the skin area with a red color, on a scale of $0-3: 0=<25 \%$ of the fruit skin red; $1=\geq 25 \%$ up to $50 \%$ of the fruit skin red; $2=\geq 50$ $\%$ up to $75 \%$ of the fruit skin red; $3=\geq 75 \%$ of the fruit skin red. The average was obtained by multiplying the total number of fruit by their respective red skin level, this product was then divided by the total number of fruit in the sample; xiii) mass loss: obtained by the difference of weight before and after storage, results expressed in percentage of mass loss of initial mass; xiv) titratable acidity: obtained by titration with $0.1 \mathrm{M} \mathrm{NaOH}$ of a solution with $10 \mathrm{~mL}$ of juice diluted in $100 \mathrm{~mL}$ distilled water, until $\mathrm{pH} 8.1$ was reached, data expressed in $\mathrm{mEq}$ $\left.100 \mathrm{~mL}^{-1} ; \mathrm{xv}\right)$ soluble solids: obtained by refractometry, results expressed in ${ }^{\circ}$ Brix; and p) Starch index: evaluated by the methodology proposed by Streif (1984).

\section{Statistical analysis}

An analysis of variance (ANOVA) was carried out for all the parameters evaluated. When the ANOVA was significant, the parameters were compared by SkottKnott test $(p<0.05)$. The data, expressed in percentages, were transformed by the formula arc.sin $\sqrt{x / 100}$, before the ANOVA.

\section{Results and discussion}

\section{Quality analysis at harvest}

Fruit that received AVG application only had the highest starch content (lowest iodine starch index) and titratable acidity (Table 1) due to the lower respiration rate of fruit subjected to the same treatment, once organic acid was consumed in the tricarboxylic acid cycle (Steffens et al., 2007; Taiz and Zeiger, 2009). When the fruit received another growth regulator combined with AVG, the starch content was reduced, but remained higher than the control fruits (Table 1). Similar results were obtained in 'Gala' apples, where higher starch content was verified in fruits that received AVG application, in relation to control fruits (Steffens et al., 2006). Perhaps, the higher starch level in fruit with AVG application culminated in lower soluble solids (Table 1), once the starch molecules had been converted into monosaccharides by fruit ripening.

Fruit from the control treatment and AVG + NAA groups had the highest ACC oxidase enzyme activity (Table 1). However, a higher ethylene production level was only verified in control fruit. This result indicated that AVG application blocked the ACC production by ACC synthase inhibition and also proved that NAA application increased the ACC oxidase enzyme activity. Some authors suggest that auxin application stimulated the synthesis of new ACC synthase enzymes and therefore, increased ethylene production (Yu and Yang, 1979; 
Li and Yuan et al., 2008), but our study demonstrated that NAA also induced ACC oxidase enzyme activity. Pre-harvest NAA application increases the expression of genes related to ethylene biosynthesis (MdACS1 and Md$A C O 1)$, perception (MdERS1) and cell wall degradation (MdPG1) (Li and Yuan et al., 2008).

\section{Quality analysis after 8 months of storage}

After 8 months of storage, control fruits had the highest ethylene production rate and increase during shelf life (Figure 1A). The fact that higher ethylene production of control fruits is related to higher ACC oxidase enzyme activity and to higher internal ethylene concentration (Kondo et al., 2009) was also confirmed in the present study due to the high Pearson correlation between these parameters (Table 2). Fruits submitted to AVG, AVG + ethephon and AVG + NAA had an intermediate ethylene production level during shelf life. Other researchers also found that ethephon application after AVG did not increase ethylene production in 'Gala' apples (Wang and Dilley, 2001; Steffens et al., 2006) and 'Jonagold' apples (Wang and Dilley, 2001).

Fruits that received pre-harvest AVG application combined with postharvest 1-MCP and ABS exhibited the lowest ethylene production level at the opening of chambers, at plus 4 and 6 days of shelf life (Figure 1A). The lower ethylene production level of these treatments is related to the two ways in which ethylene management is employed in these treatments. In other words, the enzyme responsible for ethylene precursor production was inhibited by AVG (Yu and Yang, 1979; Ju and Curry, 2000) and the ethylene action by 1-MCP (Blankenship and Dole, 2003; Ma et al., 2006; Watkins, 2006) and by ethylene absorption (Brackmann et al., 2010; Corrêa et al., 2011).

At the opening of the chambers, control fruits and those treated with AVG + ethephon presented higher respiration rates than the other treatments (Figure 1B). It is probable that, the higher respiration rate of these fruits leads to a lower healthy fruit amount and less flesh firmness (Figure 2H and 2I). The progress in fruit ripening reduces flesh firmness by elevated metabolism (higher respiration rate) and cell wall enzyme activity (Brummell et al., 1999). However, after 2 days of shelf life, lower respiration rates were observed in fruits submitted to AVG, AVG + ethephon and AVG + NAA. A remarkable fact is that fruits that received AVG + 1-MCP and AVG + ABS exhibited the highest respiration at 2

Table 1 - Starch index, flesh firmness, titratable acidity, soluble solids, ACC oxidase enzyme activity, ethylene production and respiration rate of 'Brookfield' apples postharvest (initial analysis).

\begin{tabular}{|c|c|c|c|c|}
\hline Treatment & Starch index (1-10) & Flesh firmness & Titratable acidity & Soluble solids \\
\hline & & $\mathrm{N}$ & meq $100 \mathrm{~mL}^{-1}$ & ${ }^{\circ}$ Brix \\
\hline Control $^{a}$ & $7.74 a^{*}$ & 89.27 a & $4.90 \mathrm{~b}$ & $11.90 \mathrm{a}$ \\
\hline AVG & $4.79 c$ & $92.88 \mathrm{a}$ & $5.35 \mathrm{a}$ & $10.85 c$ \\
\hline AVG + Ethephon ${ }^{c}$ & $5.75 b$ & $91.03 \mathrm{a}$ & $4.85 b$ & $11.45 \mathrm{~b}$ \\
\hline$A V G+N A A^{d}$ & $5.61 \mathrm{~b}$ & $90.78 \mathrm{a}$ & $4.45 c$ & $11.10 \mathrm{c}$ \\
\hline \multirow[t]{3}{*}{ VC (\%) } & 4 & 2 & 3 & 1 \\
\hline & ACC oxidase & & oduction & Respiration rate \\
\hline & $\mathrm{nL} \mathrm{C} \mathrm{C}_{2} \mathrm{~g}^{-1} \mathrm{~h}^{-1}$ & & $\mathrm{~g}^{-1} \mathrm{~h}^{-1}$ & $\mathrm{~mL} \mathrm{CO} \mathrm{kg}^{-1} \mathrm{~h}^{-1}$ \\
\hline Controla $^{a}$ & $74.00 \mathrm{a}$ & & & $7.40 \mathrm{a}$ \\
\hline$A V G^{b}$ & $20.66 b$ & & & $3.97 \mathrm{c}$ \\
\hline AVG + Ethephonc & $38.59 \mathrm{~b}$ & & & $6.47 b$ \\
\hline$A V G+N A A^{d}$ & $75.08 \mathrm{a}$ & & & $5.71 b$ \\
\hline VC (\%) & 36 & & & 9 \\
\hline
\end{tabular}

${ }^{a}$ Control: Only water application before fruit harvest; ' ${ }^{\text {AVG: }}$ aminoethoxyvinylglyce applied 30 days before harvest; 'Ethephon: application 10 days before harvest; ${ }^{d N A A:}$ Auxins application 7 days before harvest; " Means followed by equal letters in the columns do not differ (Skott-Knott's test, $p<0.05$ ).

Table 2 - Pearson correlations of the variables evaluated in 'Brookfield' apples after 8 months of storage in a controlled atmosphere $\left(1.2 \mathrm{kPa} \mathrm{O}_{2}\right.$ $+2.0 \mathrm{kPa} \mathrm{CO}$ ) plus 7 days of shelf life at $20^{\circ} \mathrm{C}$.

\begin{tabular}{|c|c|c|c|c|c|c|c|c|}
\hline Correlations & Ethylene & Respiration & IEC & $\mathrm{ICO}_{2}$ & Mealiness & Heathy fruits & Flesh firmness & ACC Oxidase \\
\hline Ethylene & 1 & & & & & & & \\
\hline Respiration & 0.987 & 1 & & & & & & \\
\hline IEC & 0.932 & 0.905 & 1 & & & & & \\
\hline $\mathrm{ICO}_{2}$ & ns & ns & ns & 1 & & & & \\
\hline Mealiness & 0.872 & 0.901 & 0.859 & 0.868 & 1 & & & \\
\hline Heathy fruits & -0.925 & -0.955 & -0.869 & -0.776 & -0.980 & 1 & & \\
\hline Flesh firmness & -0.879 & -0.904 & ns & ns & -0.865 & 0.909 & 1 & \\
\hline ACC Oxidase & 0.873 & 0.907 & ns & ns & 0.854 & -0.932 & -0.917 & 1 \\
\hline
\end{tabular}

ns: No significant Pearson correlation between the variables $(p<0.05)$. 


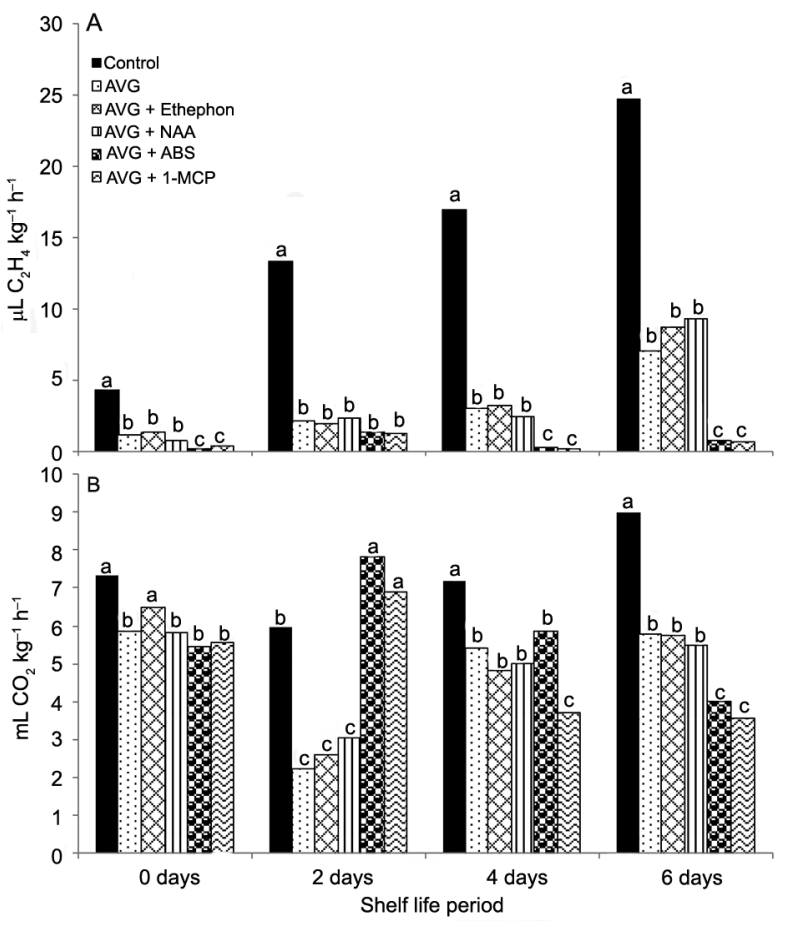

Figure 1 - Ethylene production (A) and respiration rate (B) of 'Brookfield' apples after storage for 8 months in a controlled atmosphere (1.2 $\mathrm{kPa} \mathrm{O}_{2}+2.0 \mathrm{kPa} \mathrm{CO}$ ) plus $0,2,4$ and 6 days of shelf life at $20{ }^{\circ} \mathrm{C}$. * Control: Only water application before fruit harvest. AVG: aminoethoxyvinylglyce applied 30 days before harvest. Ethephon: application 10 days before harvest. NAA: Auxins application 7 days before harvest. 1-MCP: 1-metylcyclopropene application during postharvest life (storage). ABS: Ethylene absorption in chambers by potassium permanganate sachets. ${ }^{* *}$ Means followed by equal letters, in the same shelf life day, do not differ (Skott-Knott's test, $p<0.05)$.

days of shelf life. However, after 4 and 6 days of shelf life, the respiration rates of the fruits submitted to these treatments were once again lower than all the other treatments tested (Figure 1B).

The lower respiration rate is possibly related to the lower ethylene production and IEC, considering that these characteristics have a high Pearson correlation (Table 2) and because the respiration is an ethylene triggered process (Pre-Aymard et al., 2003). The high Pearson correlations show that the ethylene production, ACC oxidase enzyme activity and respiration rate have the same response to the growth regulators. A clear climacteric peak was not observed in this study. This fact is related to the long term CA storage at a low temperature. Once apples are stored in low temperature they do not present a characteristic climacteric peak (during shelf life) after storage (Steffens et al., 2007).

ACC oxidase is the enzyme that transforms ACC into ethylene, through the oxidation of this molecule. In the present study, control and AVG + ethephon fruits exhibited the highest ACC oxidase enzyme activity; fruit that received $A V G, A V G+N A A$ and $A V G+A B S$ had intermediary activity; and fruit submitted to AVG +1 -MCP presented the lowest enzyme activity (Figure 2A). Perhaps, the lower ACC oxidase enzyme activity on fruits submitted to AVG + 1-MCP is related to the lower MdACO1 gene expression, considering that 1-MCP application decreased this gene expression in 'Fuji' and 'Golden Delicious' apples (Wakasa et al., 2006; Tatsuki et al., 2007). However, other researchers suggest that the 1-MCP did not decrease the MdACO1 gene expression in 'Orin' (Tatsuki et al., 2007) nor in 'Granny Smith' apples (Asif et al., 2009). This fact explains why the ethylene production and the IEC were so low in fruit submitted to AVG + 1-MCP, once the ACC oxidase converts ACC into ethylene (Yang and Hoffman, 1984).

Fruits from the control treatment had the highest level of IEC in relation to all other treatments (Figure $2 B)$. The IEC and ethylene production rate had the same responses to the treatment and also showed a high and positive Pearson correlation (Table 2). The higher IEC in control treatment fruit is related to the high ACC synthase and ACC oxidase enzyme activity, once there are no products inhibiting the activity of these enzymes. On the other hand, the combination AVG + ABS and AVG +1 -MCP blocked the enzyme activity; therefore, these treatments caused low IEC and ethylene production. Other researchers also found a reduction in IEC concentration when fruits were submitted to pre-harvest AVG application (Wang and Dilley, 2001; Salas et al., 2011) and postharvest 1-MCP (Watkins and Nock, 2012; Nock and Watkins, 2013).

High internal dioxide carbon concentration $\left(\mathrm{ICO}_{2}\right)$ may lead to physiological disorders, especially for $\mathrm{CO}_{2}$ susceptible apples (Castro et al., 2008). Fruit submitted to AVG + NAA, AVG + 1-MCP and AVG + ABS applications exhibited the lowest $\mathrm{ICO}_{2}$ (Figure 2C). These fruits have higher cell integrity and lower respiration rates. The higher cell integrity is related to lower mealiness and absence of flesh breakdown in fruits with lower $\mathrm{ICO}_{2}$.

Although the absence of flesh breakdown incidence can also be related to higher mass loss in fruits submitted to these treatments (Figure 3C), previous research suggests that mass loss reduces the flesh breakdown in 'Royal Gala' apples (Brackmann et al., 2007) and maintains higher quality in peaches (Prunus persica) (Pinto et al., 2012). The relationship between the two parameters $\left(\mathrm{ICO}_{2} \times\right.$ mealiness $)$ is also exhibited in the high Pearson correlation (Table 2). Perhaps the higher $\mathrm{ICO}_{2}$ in fruit with high mealiness is related to the intercellular space reduction by the soluble pectin, whereby fruit softening is a result of hydrolysis of various cell wall components, such as pectin (Prasanna et al., 2007; Payasi et al., 2009).

During postharvest, the fruit maintains the respiration pathways. Thus, oxygen must be diffused from the outside to the inside of the fruit and carbon dioxide 

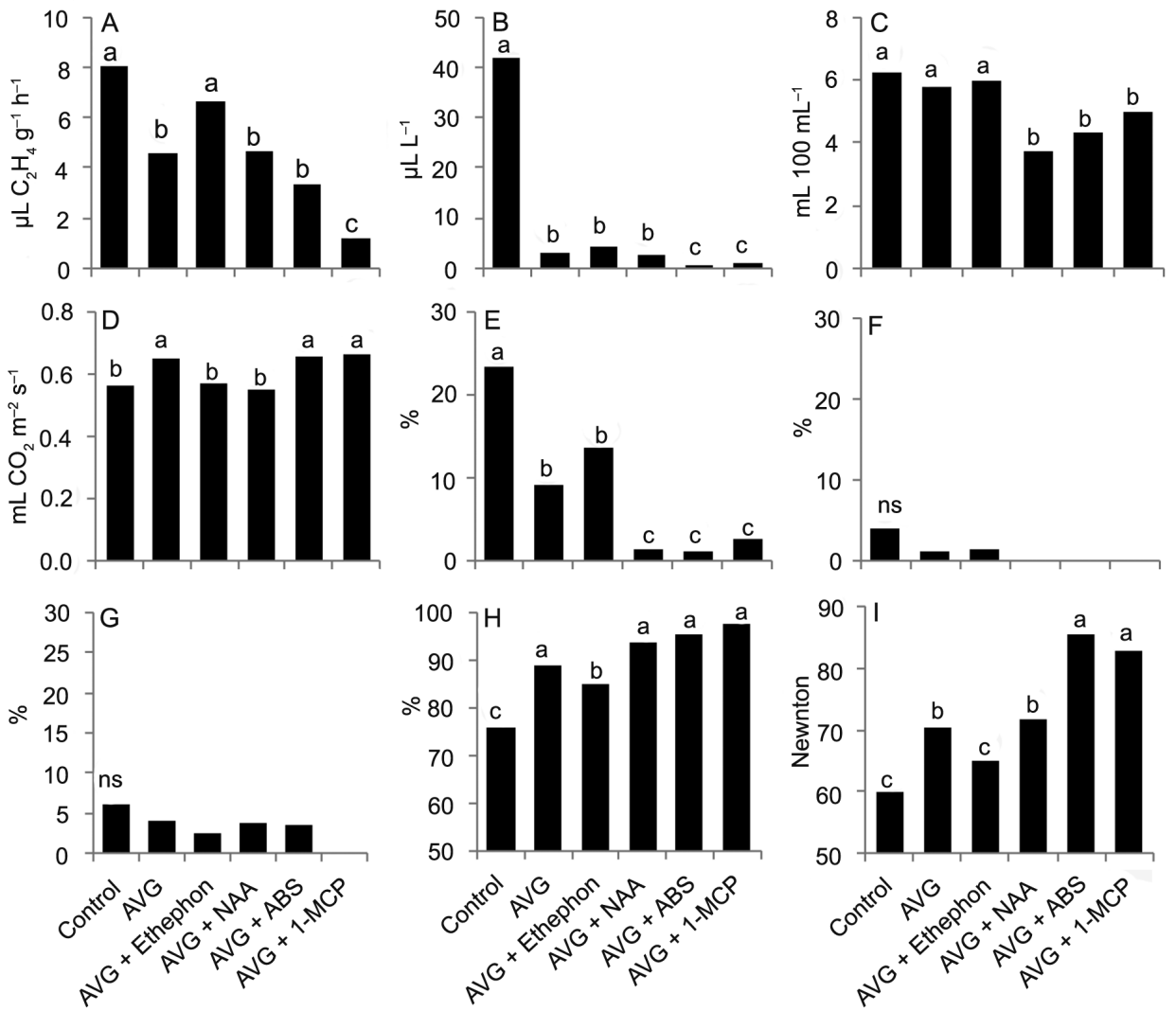

Figure 2 - ACC oxidase enzyme activity (A), internal ethylene concentration (B), internal $\mathrm{CO}_{2}$ concentration $(C)$, gas diffusion rate (D), mealiness $(\mathrm{E})$, flesh breakdown $(\mathrm{F})$, decay incidence $(\mathrm{G})$, healthy fruits $(\mathrm{H})$ and flesh firmness (I) of 'Brookfield' apples after storage for 8 months in controlled atmosphere $\left(1.2 \mathrm{kPa} \mathrm{O}_{2}+2.0 \mathrm{kPa} \mathrm{CO}\right.$ ) plus 7 days of shelf life at $20{ }^{\circ} \mathrm{C}$. ${ }^{*}$ Control: Only water application before fruit harvest. AVG: aminoethoxyvinylglyce applied 30 days before harvest. Ethephon: application 10 days before harvest. NAA: Auxins application 7 days before harvest. 1-MCP: 1-metylcyclopropene application during postharvest life (storage). ABS: Ethylene absorption in chambers by potassium permanganate sachets. * ${ }^{*}$ Means followed by equal letters, in the same parameter, do not differ by Skott-Knott's test $(p<0.05)$. ns: no significant differences between treatments.

from the inside to the outside. This fact assigns gas diffusion a fundamental role in the maintenance of high quality throughout the apple pulp (Argenta et al., 2002). Growth regulators applied in the field affected $(p<0.05)$ gas diffusion (Figure 2D). Fruits treated with AVG, AVG $+1-\mathrm{MCP}$ and AVG + ABS had the highest gas diffusion rate throughout the apple pulp. The higher gas diffusion of these fruits is a result of the higher cell wall integrity, once the gas diffuses through the intercellular spaces formed by the cell wall (Schotsmans et al., 2004; Verboven et al., 2007).

One of the main problems during apple storage is the incidence of physiological disorders, such as mealiness. This physiological disorder is characterized by low succulence and flesh with a mealy aspect. Fruit from the control treatment group showed the highest incidence of mealiness (Figure 2E), which is related to higher ethylene production and IEC, since they have a high Pearson correlation (Table 2). The effect of the ethylene on mealiness is related to cell wall enzyme activation (Prasanna et al., 2007; Goulao and Oliveira, 2008; Payasi et al., 2009). On the other hand, the combined application of $\mathrm{AVG}+\mathrm{NAA}, \mathrm{AVG}+1-\mathrm{MCP}$ and AVG + ABS suppressed $(p<0.05)$ the incidence of mealiness in relation to AVG application in isolation (Figure 2E).

Fruits from the same treatment groups did not present any symptom of flesh breakdown (Figure 2F), but there were no differences $(p>0.05)$ between the treatments. The low $\mathrm{ICO}_{2}$ is related possibly to the absence of flesh breakdown under these treatments, as well as to the internal $\mathrm{CO}_{2}$ concentration, which can influence the occurrence of physiological disorders (Castro et al., 2008).

Regarding the incidence of decay, there were no differences $(p>0.05)$ between treatments (Figure 2G). However, the decay values are very low in relation to a number of other research studies in which the researchers found a higher incidence of decay under similar storage conditions (Brackmann et al., 2009). Regarding the healthy fruit percentage, fruit submitted to AVG, AVG + 

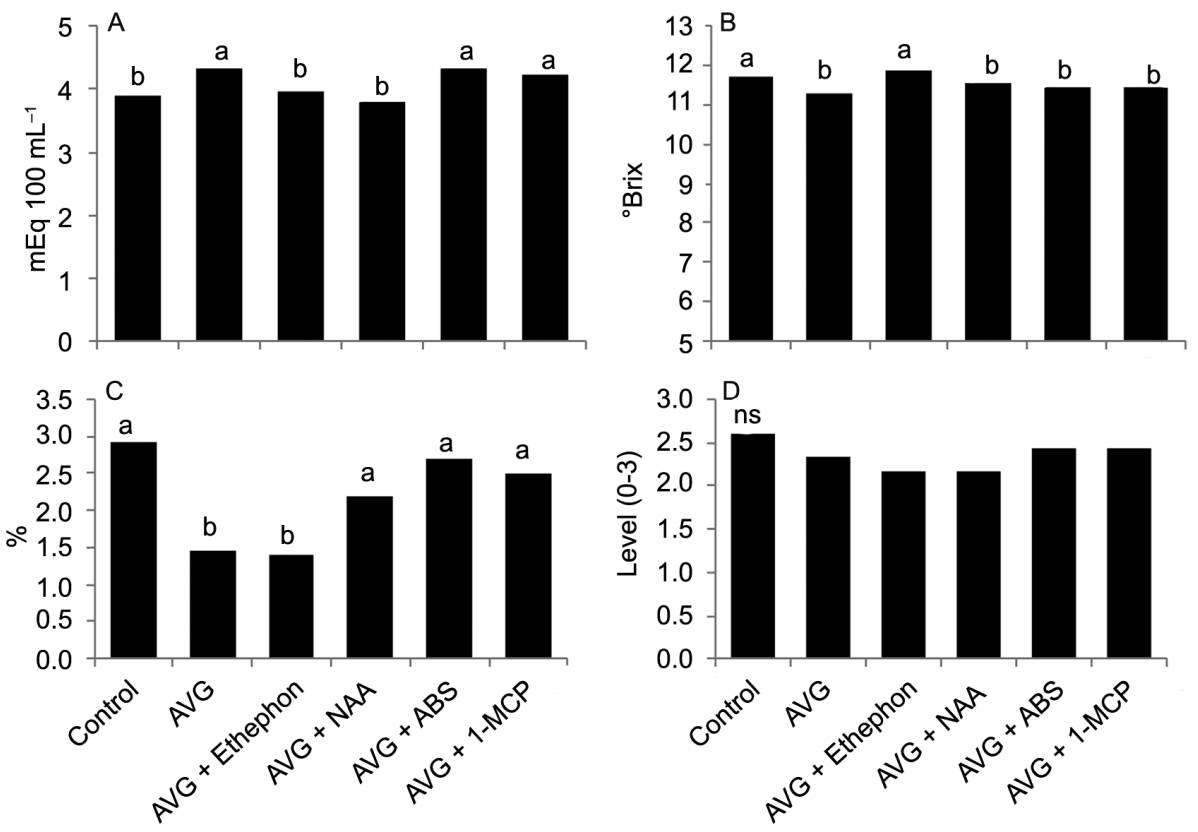

Figure 3 - Titratable acidity (A), soluble solids (B), mass loss (C) and red color index (D) of 'Brookfield' apples after storage for 8 months in controlled atmosphere $\left(1.2 \mathrm{kPa} \mathrm{O}_{2}+2.0 \mathrm{kPa} \mathrm{CO}\right)$ plus 7 days of shelf life at $20{ }^{\circ} \mathrm{C}$. ${ }^{*}$ Control: Only water application before fruit harvest. AVG: aminoethoxyvinylglyce applied 30 days before harvest. Ethephon: application 10 days before harvest. NAA: Auxins application 7 days before harvest. 1-MCP: 1-metylcyclopropene application during postharvest life (storage). ABS: Ethylene absorption in chambers by potassium permanganate sachets. ${ }^{*}$ Red skin color index: assessed subjectively through the identification of the skin area with red color, on a scale of $0-3: 0=<25 \%$ of the fruit skin red; $1=\geq 25 \%$ up to $50 \%$ of the fruit skin red; $2=\geq 50 \%$ up to $75 \%$ of the fruit skin red; $3=\geq 75 \%$ of the fruit skin red. ${ }^{* *}$ Means followed by equal letters, in the same parameter, do not differ by Skott-Knott's test, at $5 \%$ probability $(p<0.05)$. ns: no significant differences between treatments.

$\mathrm{NAA}, \mathrm{AVG}+1-\mathrm{MCP}$ and AVG + ABS had the highest values (Figure $2 \mathrm{H}$ ). The highest percentage of healthy fruits subjected to these treatments has an inverse relationship with ethylene production, respiration rate, IEC and mealiness (Table 2). The incidence of less healthy fruit, when fruits were treated with ethephon after AVG, is probably related to the ethephon transformation in ethylene, which advances fruit ripening and increases its fungal susceptibility. Nevertheless, the samples submitted to AVG + ethephon had a higher percentage of healthy fruit compared to control fruits.

Flesh firmness is one of the best indicators of the postharvest quality of apples. Fruit subjected to AVG + 1-MCP and AVG + ABS, maintained the highest flesh firmness in relation to all other treatments (Figure 2I). The greater flesh firmness under these treatments is a result of the lower ethylene production, once they have an inverse Pearson correlation (Table 2). Fruit softening is a complex process that involves three steps: the loss of cell wall mediated by expansins, depolymerization of hemicelluloses and polyuronide section by polygalacturonase or other hydrolytic enzymes (Brummell et al., 1999). Thus, fruit subjected to these treatments have less cell wall enzyme activity and ethylene is necessary to initialize this enzyme activity (Nishiyama et al., 2007;
Prasanna et al., 2007; Goulao and Oliveira, 2008; Payasi et al., 2009).

In melons (Cucumis melo), the 1-MCP application stopped fruit softening, suggesting that fruit softening is an ethylene-dependent event (Nishiyama et al., 2007). Fruit subjected to ethephon application after AVG had less flesh firmness than the ones that received AVG application only (Figure 2I). Wang and Dilley (2001) also found a reduction in flesh firmness by ethephon application in 'Gala' and 'Jonagold' apples. However, no flesh firmness reduction was observed in 'Gala' apples produced in Brazil when ethephon was applied after AVG (Steffens et al., 2006).

The titratable acidity and combined soluble solids are very important flavor components. Fruit subjected to $\mathrm{AVG}, \mathrm{AVG}+1-\mathrm{MCP}$ and $\mathrm{AVG}+\mathrm{ABS}$ had the highest titratable acidity (Figure 3A). Perhaps, the higher titratable acidity is related to the lower respiration rate, once the organic acids are consumed in the Krebs cycle (Steffens et al., 2007; Taiz and Zeiger, 2009). Higher soluble solids were observed in fruits in the control treatment group and subjected to AVG + ethephon application (Figure 3B). The higher soluble solids of these treatments are related to the hydrolysis of the cell wall molecules, represented by less flesh firmness (Figure 2I). Pinto et 
al. (2012) also attribute the increase in soluble solids to the occurrence of flesh firmness reduction (However, the variation between the treatments is very low, from 11.30 up to $11.85^{\circ}$ Brix).

Mass loss results in income loss for the storage companies. Mass loss occurs in two ways: water loss by transpiration and dioxide carbon loss by respiration rate (Brackmann et al., 2014). These authors also found that $24 \%$ of mass loss occurs as a function of respiration rate and is affected by storage conditions. Fruit treated with pre-harvest AVG and AVG + ethephon showed lower mass loss (Figure 3C). The lower mass loss in the fruits that received these treatments results in higher profit for the storer, but it can induce physiological disorders during storage. In 'Royal Gala' apples, $3 \%$ of mass loss culminated in a reduction of mealiness and flesh breakdown (Brackmann et al., 2007) and also promoted a decrease in ethylene production and ACC oxidase enzyme activity in 'Eragil' peaches (Pinto et al., 2012).

One of the main attributes observed by consumers is the external quality of the fruits, such as its red coloration. Some authors have identified a less intense red skin color of the fruits when treated with AVG (Wang and Dilley, 2001; Awad and Jager, 2002; Steffens et al., 2006), a result of the ethylene production inhibition and, therefore, a lower expression of the anthocyanin gene (Awad and Jager, 2002). However, in our research the growth regulators applied in the field and the postharvest storage techniques did not influence the fruits red skin color index (Figure 3D).

The high incidence of red skin color in the fruits, even when these were treated with growth regulators, is perhaps due to the intense red color of 'Brookfield' apples. Thus, the AVG application may reduce the red skin color, but this reduction is not significant for this 'Gala' strain. No increase in the red skin color of the fruits with the application of ethephon after AVG in the present study, which is in disagreement with prior research studies (Wang and Dilley, 2001; Steffens et al., 2006; Ban et al., 2007). Again, this result can be attributed to the high red skin coloration of this cultivar.

\section{Conclusions}

Pre-harvest AVG application, combined with postharvest application of either 1-MCP or ABS, reduced ethylene production, IEC and respiration rate and maintained a level of greater flesh firmness after 8 months of storage.

AVG application, with or without another technique, did not affect the red skin color of 'Brookfield' apples. The naphthaleneacetic acid application induced ACC oxidase enzyme activity at harvest, but not after storage.

Ethephon (2.0 $\mathrm{L} \mathrm{ha}^{-1}$ ) associated with AVG depressed the postharvest quality of apples in comparison to the treatment of AVG alone or AVG plus 1-MCP and AVG plus ABS.

\section{References}

Argenta, L.; Fan, X.; Mattheis, J. 2002. Impact of watercore on gas permeance and incidence of internal disorders in 'Fuji' apples. Postharvest Biology and Technology 24: 113-122.

Asif, M.H.; Pathak, N.; Solomos, T.; Trivedi, P.K. 2009. Effect of low oxygen, temperature and 1-methylcyclopropene on the expression of genes regulating ethylene biosynthesis and perception during ripening in apple. South African Journal of Botany 75: 137-144.

Awad, M.A.; Jager, A. 2002. Formation of flavonoids, especially anthocyanin and chlorogenic acid in 'Jonagold' apple skin: influences of growth regulators and fruit maturity. Scientia Horticulturae 93: 257-266.

Ban, T.; Kugishima, M.; Ogata, T.; Shiozaki, S.; Horiuchi, S.; Ueda, H. 2007. Effect of ethephon (2-chloroethylphosphonic acid) on the fruit ripening characters of rabbiteye blueberry. Scientia Horticulturae 112: 278-28.

Black, B.L.; Bukovac, M.J.; Hull, J. 1995. Effect of spray volume and time of NAA application on fruit size and cropping of Redchief 'Delicious' apple. Scientia Horticulturae 64: 253-264.

Brackmann, A.; Pinto, J.A.V.; Weber, A.; Neuwald, D.A.; Steffens, C.A. 2007. Mass loss induction and physiological disorders in 'Royal Gala' apples during controlled atmosphere storage. Revista Brasileira de Armazenamento 32: 87-92 (in Portuguese, with abstract in English)

Brackmann, A.; Weber, A.; Pavanello, E.P.; Both, V.; Sestari, I. 2009. Controlled atmosphere storage of Gala mutants apple. Revista Brasileira de Armazenamento 34: 136-143 (in Portuguese, with abstract in English).

Brackmann, A.; Anese, R.O.; Pinto, J.A.V.; Both, V.; Venturini, T.L.; Schorr, M.R. 2010. Application of 1-methylcyclopropene and ethylene absorption on 'Royal Gala' apple late harvested. Ciência Rural 40: 2074-2080 (in Portuguese, with abstract in English).

Brackmann, A.; Pavanello, E.P.; Weber, A.; Both, V.; Pinto, J.A.V. 2011. Relative humidity and ethylene control during 'Royal Gala' apples storage. Revista Brasileira de Armazenamento 36: 103-108 (in Portuguese, with abstract in English).

Brackmann, A.; Thewes, F.R.; Anese, R.O.; Both, V.; Gasperin, A.R. 2014. Respiration rate and its effect on mass loss and chemical qualities of 'Fuyu' persimmon fruit stored in controlled atmosphere. Ciência Rural 44: 612-615.

Brummell, D.A.; Harpster, M.H.; Civello, P.M.; Palys, J.M.; Bennett, A.B.; Dunsmuir, P. 1999. Modification of expansin protein abundance in tomato fruit alters softening and cell wall polymer metabolism during ripening. Plant Cell 11: 2203-2216.

Bufler, G. 1986. Ethylene-promoted conversion of 1-aminocyclopropene1-carboxylic acid to ethylene in peel of apple at various stages of fruit development. Plant Physiology 80: 539-543.

Castro, E.; Barrett, D.M.; Jobling, J.; Mitcham, E.J. 2008. Biochemical factors associated with a $\mathrm{CO}_{2}$ induced flesh browning disorder of Pink Lady apples. Postharvest Biology and Technology 48: 182-191.

Corrêa, T.R.; Steffens, C.A.; Tanaka, H.; Amarante, C.V.T.; Brackmann, A.; Anese, R.O. 2011. 'Laetitia' plums stored in controlled atmosphere and active modified atmosphere packing with ethylene management. Revista Brasileira de Fruticultura 33: 723-729 (in Portuguese, with abstract in English). 
Goulao, L.F.; Oliveira, C.M. 2008. Cell wall modifications during fruit ripening: when a fruit is not the fruit. Food Science and Technology 19: 4-25.

Huai, Q.; Xia, Y.; Chen, Y.; Callahan, B.; Li, N.; Ke, H. 2001. Crystal structure of 1- aminocyclopropane-1-carboxylate (ACC) synthase in complex with aminoethoxyvinylglycine and pyridoxal-5'phosphate provide new insights into catalytic mechanisms. Journal of Biological Chemistry 276: 3821038216.

Ju, Z.; Curry, E.A. 2000. Evidences that $\alpha$-farnensene biosynthesis during fruit ripening is mediated by ethylene regulated gene expression in apples. Postharvest Biology and Technology 19: 9-16.

Li, Z.; Gemma, H.; Iwahori, S. 2001. Stimulation of 'Fuji' apple skin color by ethephon and phosphorus-calcium mixed compounds in relation to flavonoid synthesis. Scientia Horticulturae 94: 193-199.

Li, J.; Yuan, R. 2008. NAA and ethylene regulate expression of genes related to ethylene biosynthesis, perception, and cell wall degradation during fruit abscission and ripening in 'Delicious' apples. Journal of Plant Growth Regulators 27: 283-295.

Ma, B.; Cui, M.; Sun, H.; Takada, K.; Mori, H.; Kamada, H.; Ezura, H. 2006. Subcellular localization and membrane topology of the melon ethylene receptor CmERS1. Plant Physiology 141: 587-597.

Mannapperuma, J.D.; Singh, R.P.; Montero, M.E. 1991. Simultaneous gas diffusion and chemical reaction in foods stored in modified atmosphere. Journal of Food Engineering 14: 167-183.

Nishiyama, K.; Guis, M.; Rose, J.K.C.; Kubo, Y.; Bennett, K.A.B.; Lu, W.; Kato, K.; Koichiro, U.; Ryohei, N.; Akitsugu, I.; Mondher, B.; Alain, L.; Jean-Claude, P.; Bennett, A.B. 2007. Ethylene regulation of fruit softening and cell wall disassembly in charentais melon. Journal of Experimental Botany 58: 12811290.

Nock, J.F.; Watkins, C.B. 2013. Repeated treatment of apple fruit with 1-methylcyclopropene (1-MCP) prior to controlled atmosphere storage. Postharvest Biology and Technology 79: 73-79.

Payasi, A.; Mishra, N.N.; Chaves, A.L.S.; Singh, R. 2009. Biochemistry of fruit softening: an overview. Physiology and Molecular Biology of Plants 15: 103-113.

Pinto, J.A.V.; Brackmann, A.; Schorr, M.R.W.; Venturini, T.L.; Thewes, F.R. 2012. Induction of mass loss in postharvest quality of 'Eragil' peaches in cold storage. Ciência Rural 42: 962-968 (in Portuguese, with abstract in English).

Prasanna, V.; Prabha, T.N.; Tharanathan, R.N. 2007. Fruit ripening phenomena: an overview. Critical Review in Food Science and Nutrition 47: 1-19.

Pre-Aymard, C.; Weksler, A.; Lurie, S. 2003. Responses of 'Anna', a rapidly ripening summer apple, to 1-methylcyclopropene. Postharvest Biology and Technology 27: 163-170.

Salas, N.A.; Molina-Corral, F.J.; Gonzáles-Aguilar, G.A.; Otero, A.; Sepulveda, D.R.; Olivas, G.I. 2011. Volatile production by 'Golden delicious' apples is affected by preharvest application of aminoethoxyvinylglycine. Scientia Horticulturae 130: 436444.
Schotsmans, W.; Verlinden, B.E.; Lammertyn, J.; Nicolai, B.M. 2003. Simultaneous measurement of oxygen and carbon dioxide diffusivity in pear fruit tissue. Postharvest Biology Technology 29: 155-166.

Schotsmans, W.; Verlinden, B.E.; Lammertyn, J.; Nicolai, B.M. 2004. The relationship between gas transport properties and the histology of apple. Journal of the Food Science and Agriculture 84: 1131-1140.

Steffens, C.A.; Guarienti, A.J.W.; Storck, L.; Brackmann, A. 2006. Maturation of the 'Gala' apple with preharvest sprays of aminoethoxyvynilglycine and ethephon. Ciência Rural 36: 434-440 (in Portuguese, with abstract in English).

Steffens, C.A.; Brackmann, A.; Pinto, J.A.V.; Eisermann, A.C. 2007. Respiratory rate of fruits of temperate climate. Pesquisa Agropecuária Brasileira 42: 313-321 (in Portuguese, with abstract in English).

Streif, J. 1984. Maturity evaluation by iodine-starch test in apple = Jod-Stärke-test zur beurteilung der fruchtreif bei Äpfeln. Obst und Garten 8: 12 (in Germany).

Taiz, L.; Zeiger, E. 2009. Plant Physiology. 4ed. Artmed, Porto Alegre, RS, Brazil.

Tatsuki, M.; Endo, A.; Ohkawa, H. 2007. Influence of time from harvest to $1-\mathrm{MCP}$ treatment on apple fruit quality and expression of genes for ethylene biosynthesis enzymes and ethylene receptors. Postharvest Biology and Technology 43: 28-35.

Unrath, C.R.; Obermiller, J.D.; Green, A.; McArtney, S.J. 2009. The effects of aminoethoxyvinylglycine and naphthaleneacetic acid treatments on abscission and firmness of 'Scarletspur Delicious' apples at normal and delayed harvests. HortTechnology 19: 620-625.

Wang, Z.; Dilley, D.R. 2001. Aminoethoxyvinylglycine, combined with ethephon, can enhanced red color development without over-ripening apples. Hortscience 36: 328-331.

Wakasa, Y.; Kudo, H.; Ishikawa, R.; Akada, S.; Senda, M.; Niizeki, M.; Harada, T. 2006. Low expression of an endopolygalacturonase gene in apple fruit with long-term storage potential. Postharvest Biology and Technology 39: 193198.

Watkins, C.B. 2006. The use of 1-metylcyclopropene (1-MCP) on fruit and vegetables. Biotechnology Advances 24: 389-409.

Watkins, C.B.; Nock, J.F. 2012. Rapid 1-methylcyclopropene (1$\mathrm{MCP}$ ) treatment and delayed controlled atmosphere storage of apples. Postharvest Biology and Technology 69: 24-31.

Yang, S.F.; Hoffman, N.E. 1984. Ethylene biosynthesis and its regulation in higher plants. Annual Review of Plant Physiology 35: $155-189$.

Yildiz, K.; Ozturk, B.; Ozkan, Y. 2012. Effects of aminoethoxyvinylglycine (AVG) on preharvest fruit drop, fruit maturity, and quality of 'Red Chief' apple. Scientia Horticulturae 144: 121-124.

Yu, Y.B.; Yang, S.F. 1979. Auxin-induced ethylene production and its inhibitors by aminoethoxyvinylglycine and cobalt ion. Plant Physiology 64: 1074-1077.

Yuan, R.; Carbaugh, D.H. 2007. Effect of NAA, AVG, and 1-MCP on ethylene biosynthesis, preharvest fruit drop, fruit maturity, and quality of 'Golden Supreme' and 'Golden Delicious' apples. Hortscience 42: 101-105. 